\title{
プレート境界地震の震源域を考慮した地震危険度解析 SEISMIC HAZARD ANALYSIS USING SOURCE MODELS FOR INTERPLATE EARTHQUAKES
}

\author{
井上 超*, 神田 順** \\ Takashi INOUE and Jun KANDA
}

\begin{abstract}
Seismic hazard of Tokyo and Osaka areas is evaluated by the Probabilistic Model Method and the Cumulative Distribution Method using historical earthquake data of 300 years and the Kanai's attenuation relationship. The hazard curve obtained by the Probabilistic Model Method almost agrees with the result by the Cumulative Distribution Method. Seismic source areas of interplate earthquakes are separately modeled. The seismic hazard of the Tokyo area is greatly affected by the extent of the source area. Seismic hazard based on nonstationary earthquake occurrences at the interplate faults is also studied.
\end{abstract}

Keywords : seismic hazard, probabilistic model, source area, interplate, nonstationarity 地震危険度, 確率モデル，震源域，プレート境界，非定常

\section{1.はじめに}

定常な地震発生に基づく地震危険度の評価方法としてて は，大別して地震発生の確率モデルに基づく方法と累積 頻度分布による方法がある1”。前者は，地震発生の確率 モデルから地動強度年最大值の確率分布を求める方法で あり；確率モデルのパラメータは地震カタログや活断層 データに基づいて推定される2)。後者は, 地震カタログ 亡距離减衰式を用いて対象地点での過去の地震による地 震動強さを推定し，その累積頻度分布から再現期待値を 求める方法である ${ }^{3)}$ 。累積頻度分布に極值分布を当ては める場合もある。

確率モデルによる手法では, 地震カタログや活断層 データに基づき地震発生確率モデルのパラメータを設定 することができるが,確率モデルの妥当性が問題となる。 累積頻度分布による方法は, 地震カタログをそのまま用 いるという点で明快な方法であるが，地震資料が時間的 空間的に不均質であり，地震動レベルの上限値付近の議 論を行う場合には，大地震のデータが十分ではないとい う問題がある。これら二つの手法による結果を比較し, それぞれの手法の欠点を補うことを目的として, 地震危 険度評価の一つの手法を提案する。

歴史地震デー夕を補うために，陸上活断層デー夕を用
いた確率モデルによる地震危険度解析では, 東京など推 積層の厚い地域においては活断層の存在自体が不明とい う問題がある()。プレート境界では内陸活断層に比へ， 比較的短い繰返し間隔で大地震が発生し, 東京や大阪な どの大都市に大きな被害をもたらしてきた。本論文では, プレート境界地震の震源域を他の地震の震源域と分離し て用いる形の手法を提案し，例題として東京および大阪 地域の地震危険度を評価して累積頻度分布による結果と 比較した。また，プレート境界地震の繰返しの影響を地 震危険度評価に反映させるべきと考え, 単純なモデルに より地震発生の非定常性を考慮した。

\section{2. 解析手法}

\section{1) 解析条件}

解析対象地域は, 図一1に示す東京および大阪の市街 地を中心とした緯度, 経度 $3^{\circ}$ の範囲とし, 地震危険度 を求める地点は, 東京では $35.7^{\circ} \mathrm{N}, 139.7^{\circ} \mathrm{E}$, 大阪で は $34.7^{\circ} \mathrm{N}, .135 .5^{\circ} \mathrm{E}$ の地点とした。歴史地震資料とし ては, 比較的信頼性の高い過去 300 年間（1686 年一 1985 年) の資料を用いることとし ${ }^{5)}, 1686$ 年から 1884 年は宇佐美カタログ6)，1885 年から 1925 年は宇津力夕 ログク，1926年から1985年は気象府地震月報8を用いた。

\footnotetext{
本論文の一部は日本建築学会大会 1992.8 において発表した。

* ハザマ技術研究所 主任研究員・M.S.

** 東京大学工学部建築学科 助教授. Ph. D.
}

Senior Research Engineer, Technical Research Inst. 'Hazama Corporation, M.S:

Assoc. Prof,, Dept. of Architecture, Faculty of Engineering, Univ. of Tokyo, Ph.D. 

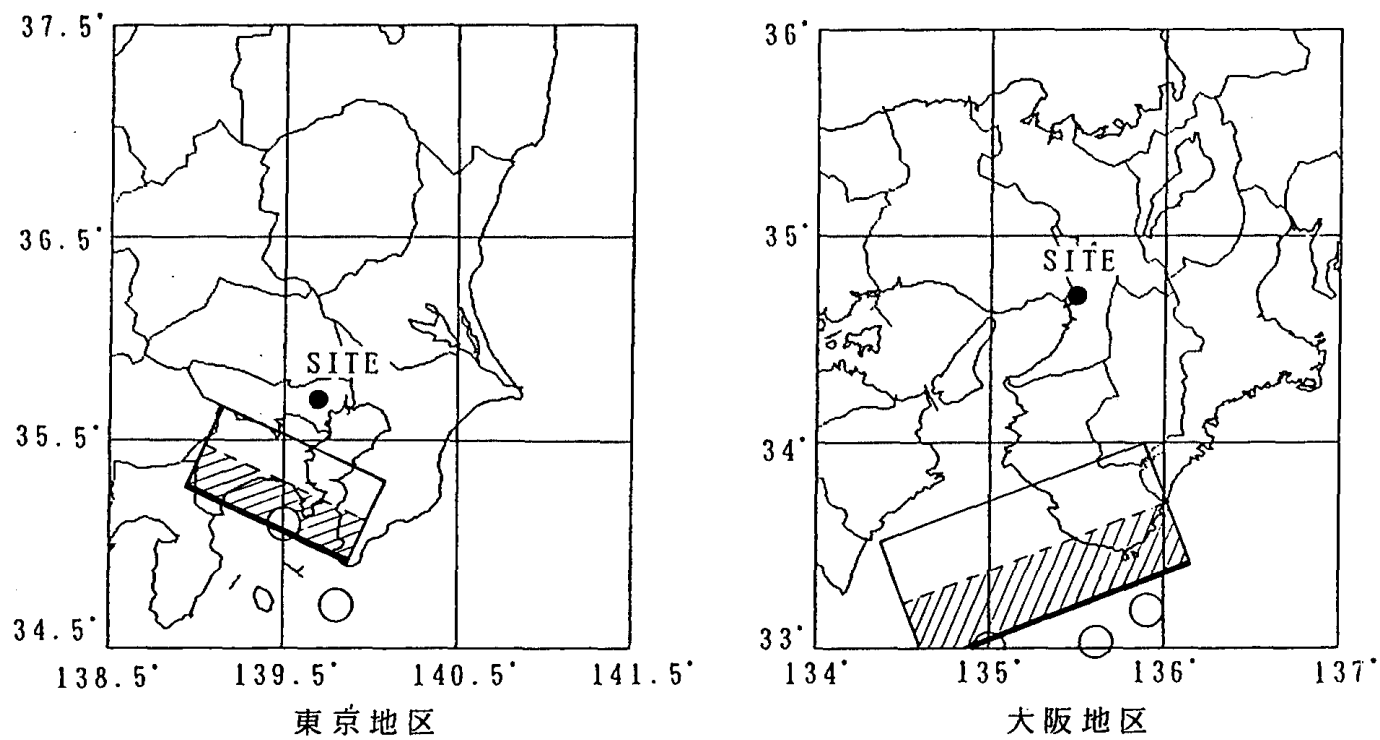

図-1 解析対象範囲

震源深さは古い地震では明らかでないため, 平均的な值 としてすべて $30 \mathrm{~km}$ とした。基盤速度 $v_{0}(\mathrm{~cm} / \mathrm{sec})$ の 距離減衰式としては，次式で表される金井式"9)用いた。

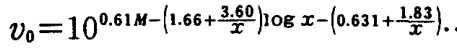

ここで， $M$ はマグニチュード， $x$ は震源距離である。 距離減衰式のばらつきは考慮しない。

2）確率モデルによる地震危険度解析 ${ }^{2), 10)}$

ある地点の地震動の大きさ $Y$ がある値 $y$ を超過する 確率は, マグニチュードと震源距離を確率変数としたと き，次式で表される。

$$
P(Y>y)=\int_{M} \int_{X} P(Y>y \mid m, x) f_{M}(m) f_{X}(x) d m d x
$$

ここで $f_{M}(m), f_{X}(x)$ はそれぞれマグニチュード $M$ と震 源距離 $X$ の確率密度関数, $P(Y>y \mid m, x)$ はマグニ チュードと震源距離が与えられたとき, 距離減衰式から 定まる条件付き確率である。地震発生の規模別分布が

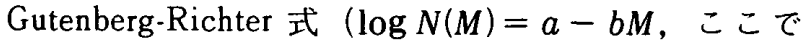
$N(M)$ はマグニチュードが $M$ 以上の地震の数, $a, b$ は 定数）に従い，対象とするマグニチュードの上下限值を それぞれ $m_{1}, m_{0}$ とすれば

$$
f_{M}(m)=\frac{\beta \exp \left\{-\beta\left(m-m_{0}\right)\right\}}{1-\exp \left\{-\beta\left(m_{\mathrm{t}}-m_{0}\right)\right\}}
$$

ここで $\beta=b \ln (10) 。 f_{X}(x)$ は震源域とサイトの位置関係 から決定される。 $m_{0}$ 以上の地震の年間発生率を 地震発生がポアンン過程に従うと仮定すれば, $\Delta t$ 年間 の超過確率は,

$$
P\left(Y_{\Delta t}>y\right)=1-\exp \{-\nu \Delta t P(Y>y)\}
$$
となる。

解析には McGuire のプログラム EQRISK ${ }^{11)}$ を用い た。このプログラムは (2) 式の積分を離散的に実行す るもので, 震源距離については震源域内をサイトを中心
とする半径方向に 50 分割し，マグニチュードについて は増分を 0.05 とした。

3）累積頻度分布による地震危険度解析

累積頻度分布による地震危険度解析には, 壇・神田 ${ }^{5)}$ の方法を用いる。壇らは歴史地震に金井式を適用し, サ イトを中心とした半径 $R$ 内の平均地震基盤速度 $v_{\mathrm{est}}$ を 求めた。 $R$ は平均化を施す半径であり, 震源近傍での 距離減衰式の適用性の問題から, 地震危険度解析では適 切な半径 $R$ を設定することが必要と考えられるが，こ こでは壇らにならって $40 \mathrm{~km}$ とした。統計年数 $T_{s}$ 年間 の平均地震基盤速度 $v_{\text {est }}$ の年最大值を大きさの順に並 ベ代え, $n$ 番目の年最大值を $v_{\text {est } n}$ とすると, 非超過確 率 $F_{n}$ はHazen 式を用いて

$$
F_{n}=1-\frac{n-0.5}{T_{s}}
$$

で与えられる。壇らは, 累積頻度分布に上下限储を有す る極值分布を当てはめ基盤速度の上限值の存在を示唆し ている。

\section{3. 緯度経度 $1^{\circ}$ 角の震源域による地震危険度解析}

確率モデルに用いる Gutenberg-Richter 式の係数は, 緯度, 経度 $1^{\circ}$ (ほぼ $100 \mathrm{~km}$ 角) の範囲ごとに歴史地震 データに基づき決定した。Katayama の方法"2》を参考に して，宇佐美の資料では $M \geqq 7.5$ ，宇津カタログでは $M \geqq 6.0$, 気象庁地震月報では $M \geqq 5.0$ の地震記録だけ を用い, 各マグニチュードの地震の年間発生率の累積值 から最小三乗法によって, Gutenberg-Richter 式の係数 $a$ と $b$ を決定した。 $M \geqq 5.0$ の年間地震発生率は, Gutenberg-Richter 式より求めている。各領域 $\sigma b$ 值, $M \geqq 5.0$ の年間地震発生率レを図一2に示す。鼠大マグ ニチュード $m_{1}$ の決定には，できるだけ長期間の地震記 録を用いるべきという考えに従い，各領域の 1307 年間 


\begin{tabular}{|c|c|c|c|}
$37.5^{\circ}$ & $\begin{array}{l}0.82 \\
0.21\end{array}$ & $\begin{array}{l}1.04 \\
0.35\end{array}$ & $\begin{array}{l}1.22 \\
3.49\end{array}$ \\
\cline { 2 - 4 } $36.5^{\circ}$ & 0.80 & 1.06 & 1.44 \\
$35.5^{\circ}$ & 0.64 & 2.48 & 6.77 \\
\cline { 2 - 4 } $34.5^{\circ}$ & $(8.91)$ & $(8.84)$ & 0.78 \\
$(1.59)$ & $(1.37)$ & 0.66 \\
\hline
\end{tabular}

$138.5^{\circ} \quad 139.5^{\circ} \quad 140.5^{\circ} \quad 141.5^{\circ}$.

東京地区

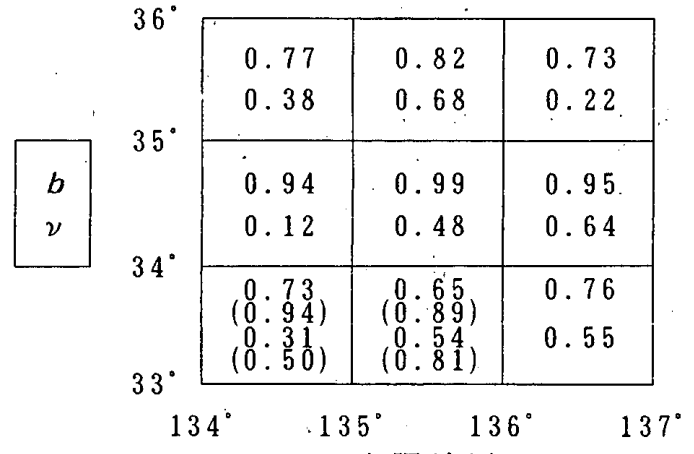

大阪地区

（）内の数字はプレート境界の大地震を除いた場合の值

図一2 緯度経度 $1^{\circ}$ 角震源域のパラメータ

\begin{tabular}{|c|c|c|c|}
\hline $37.5^{\circ}$ & $\begin{array}{l}7.5 \\
.7 .75\end{array}$ & $\begin{array}{l}7.5 \\
7.75\end{array}$ & $\begin{array}{l}7.5 \\
7.75\end{array}$ \\
\hline $36.5^{\circ}$ & 7.5 & 7.5 & 7.5 \\
\hline$\cdot$ & 7.75 & 7.75 & 7.75 \\
\hline & $\begin{array}{c}7.9 \\
(7.4) \\
8.0\end{array}$ & $\begin{array}{c}8.1 \\
(7.3) \\
8.0\end{array}$ & $\begin{array}{l}7.5 \\
8.0\end{array}$ \\
\hline
\end{tabular}

$138.5^{\circ} 139.5^{\circ} 140.5^{\circ} 141.5^{\circ}$ 東京地区

\begin{tabular}{l|l|l|l|}
$36^{\circ}$ & \multicolumn{1}{|c|}{$\begin{array}{l}7.2 \\
7.75\end{array}$} & $\begin{array}{l}7.4 \\
7.75\end{array}$ & $\begin{array}{l}8.0 \\
8.0\end{array}$ \\
\cline { 2 - 4 } $34^{\circ}$ & $\begin{array}{l}7.0 \\
7.75\end{array}$ & $\begin{array}{l}7.5 \\
7.75\end{array}$ & $\begin{array}{l}7.6 \\
7.75\end{array}$ \\
\cline { 2 - 4 } $33^{\circ}$ & $\begin{array}{c}8.4 \\
(7.0) \\
8.5\end{array}$ & $\begin{array}{c}8.4 \\
7.5) \\
8.5\end{array}$ & 7.9 \\
\cline { 2 - 4 } $134^{\circ}$ & \multicolumn{3}{|c|}{$135^{\circ}$} \\
大阪地区
\end{tabular}

大阪地区

上段：1307年間の最大值 下段：地震地体構造に基づく最大值

（）内の数字はプレート境界の大地震を除いた場合の值

図一-3 緯度経度 $1^{\circ}$ 角震源域の最大マグニチュード
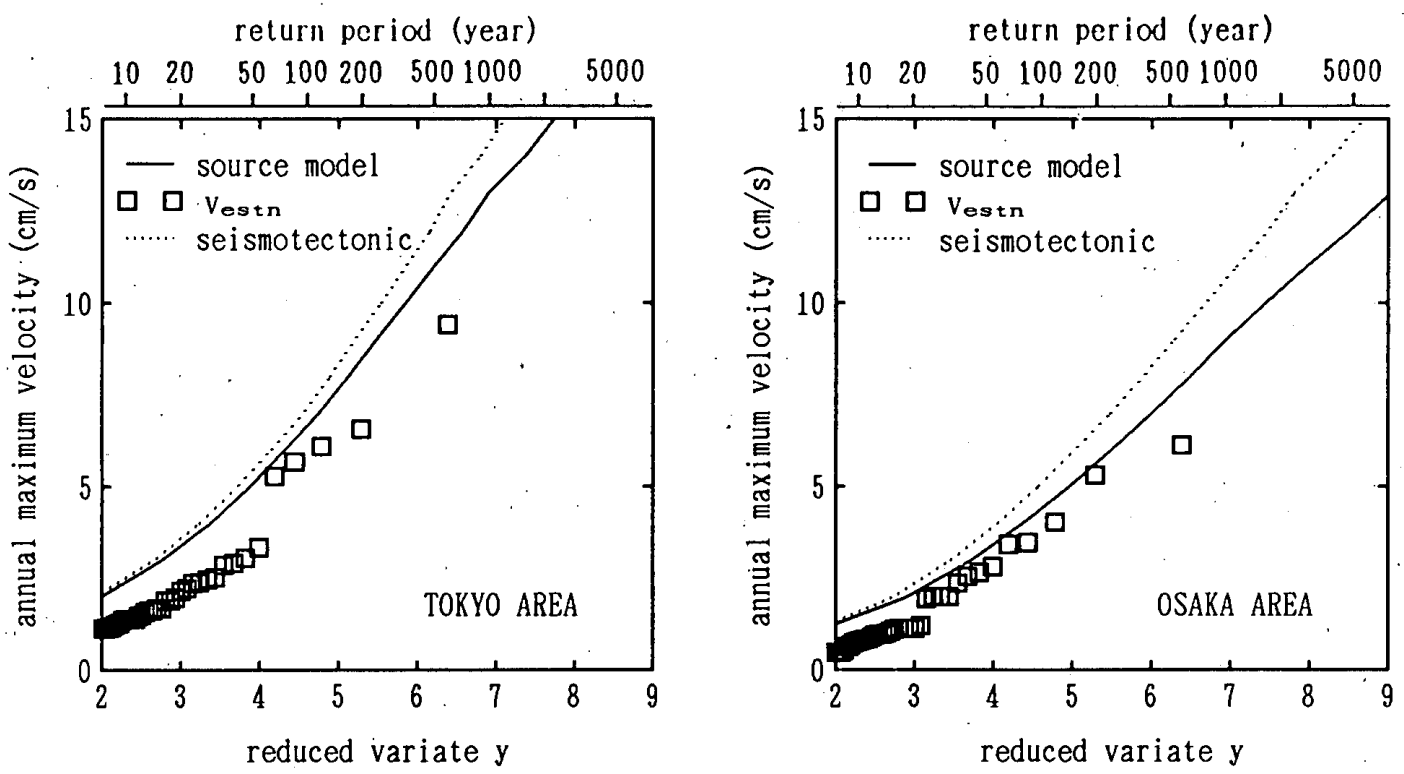

図一4 累積頻度分布と確率モデルによる地震危険度解析

の地震記録中（679 年〜1985 年 $)^{6) ~ 8)}$ の最大值を用いた。 また比較のため，Makino ら ${ }^{13)}$ が地震地体構造に基づい て定めた最大マグニチュードを用いた解析も行った。最 大マグニチュードを図一 3 に示す。最小マグニチュード $m_{0}$ は 5.0 とした。

累積頻度分布による地震危険度（50 番目までの $v_{\text {est } n}$ )
と，確率モデルによって計算した地震危険度を図-4に 示す。横軸は非超過確率 $F$ の規準化変数 $y=-\ln (-\ln$ $F)$ と再現期間, 縦軸は基盤速度の年最大值である。地 震地体構造に基づく最大マグニチュードを用いた結果 も，図中に点線で示す。東京の 1,2 番目の年最大值は, それぞれ 1923 年の関東地震, 1703 年の元緑地震による 
ものであり，3－5番目の年最大值は直下型地震による。 大阪の 1,4 番目の年最大値はサイト周辺の地震による ものであり, 2,3 番目の年最大值はそれぞれ 1707 年の 宝永地震, 1891 年の濃尾地震によるものである。緯度, 経度 3 度角の解析対象範囲を広げても, 両手法とも八 ザード曲線の形状はあまり変化しない。

確率モデルによる結果は，累積頻度分布による結果よ りも，やや大きめな基盤速度值を与えるが，両手法によ る結果はおおむね一致している。基盤速度の小さい部分 で，確率モデルによる危険度が累積頻度分布によるもの よりも大きいのは, Gutenberg-Richter 式の係数を決定 する際に，観測期間に応じたマグニチュード範囲を設定 して，記録漏れの影響を取り除いていることが原因の一 つと考えられる。また，確率モデルでは，震源域の最大 マグニチュードの地震が, 震源域内で一様に発生し得る と仮定するため, サイト周辺の震源域の最大マグニ チュードの影響を受けて,規準化変数の大きいところ(超 過確率の小さいところ) で基盤速度の值は大きくなる。 累積頻度分布による方法では，基盤速度最大值をサイト 周辺で平均化しているため, サイト近傍の地震は過小評 価される。平均化を行わない場合 $(R=0 \mathrm{~km})$, 東京地 域で直下型地震が 2,3 番目の年最大值を与え, 基準化 変数 $y=5$ 付近で累積頻度分布による基盤速度値が増加 して，両手法の結果はよく一致する。東京地域のそれ以 外の部分や大阪地域では, 平均化の影響は小さい。地震 地体構造に基づく最大マグニチュードを用いた場合（図 -4の点線）は，1307 年間の地震記録中の最大マグニ チュードを用いた場合よりも，さらに大きな基盤速度と なり，累積頻度分布による結果との差が大きくなる。

\section{4. プレート境界地霞を分離したモデル}

太平洋沿岸地域における地震被害を考える場合, プ レート沈み込み部分で繰り返し発生する大地震の影響は 無視できない。プレート境界地震の繰返し間隔は，一般 にプレート内断層による地震の繰返し間隔よりも短く, 歴史地震によってある程度評価できる。ここでは相模卜 ラフ, 南海トラフの大地震を他の地震と分離したモデル を用いて地震危険度を評価する。

緯度, 経度 $1^{\circ}$ 角の震源域モデルにおいて, 相模卜ラ フで発生した大地震（1703 年元禄地震 $M=8.1,1923$ 年関東地震 $M=7.9 ）$ おび南海トラフで発生した大地 震（1707 年宝永地震 $M=8.4,1854$ 年安政南海地震 $M$ $=8.4,1946$ 年南海地震 $M=8.0)$ を除いた場合の震源 パラメータ（パラメータが変化した震源域のみ）を図一 2,3 の括孤内に示す。南海トラフを含む震源域の最大又 グニチュードは, 上記の大地震以外に, 1686 年以前に 南海トラフで発生した大地震も除いた最大マグニチュー ドを用いた。プレート境界地震の震源域を, どの範囲に

\begin{tabular}{|c|c|c|}
\hline パラメータ & 関東地震 14) & 南海地震 15$)$ \\
\hline 断層長さ $(\mathrm{km})$ & 95 & 150 \\
\hline 断層幅 $\quad(\mathrm{km})$ & 54 & 70 \\
\hline 上端樑さ $(\mathrm{km})$ & 1.9 & 10 \\
\hline 傾き角 $\left({ }^{\circ}\right)$ & 25 & 10 \\
\hline
\end{tabular}

設定するかは大きな問題を含み，限定された期間のデー タから決定することは難しい。ここでは，提案されてい る断層モデルの断層面が震源域を含むもの之仮定し，次 の 3 つのケースを考える。

CASE 1 : 断層モデル上端部の平面的位置に線震源を考 虑。線震源の深さは $30 \mathrm{~km}$ とする。

CASE 2：断層モデルの断層面（傾斜面）の上半分を面 震源とする。

CASE 3：断層モデルの断層面（傾斜面）をそのまま面 震源とする。

東京地域の断層モデルは関東地震のもの ${ }^{14)}$, 大阪地域の 断層モデルは安政南海地震のもの ${ }^{15)}$ を用いた。断層モデ ルのパラメータを表一1に示す。対象とした大地震の震 源位置（図中○印）と，断層モデルによる震源域 (CASE 1 は図中の太線, CASE 2 は図中の斜線部分) を図一1に示す。震源位置と震源域は必ずしも一致して いないが, CASE 1 は歴史地震の震源位置に近い，き わめて限定された震源域と考えられる。CASE 3 は, 提案されている断層面全体を震源域とした場合であり, CASE 2 は両者の中間的な領域である。

Wesnousky ら ${ }^{16)}$ は，1つの断層で発生する地震の規 模別分布は Gutenberg-Richter 式には従わず，断層長さ から定まる最大マグニチュードの地震が繰り返し発生す るという考えを示した。ここでは，この考え方を参考に して, 相模トラフの地震発生は, 平均発生率 0.005 $(1 / 200)^{16)}$ のポアソン過程で，マグニチュードは7.9 8.1 の一様分布, 南海卜ラフの地震発生は平均発生率 $0.00855(1 / 117)^{17)}$ のポアソン過程で，マグニチュード は8.0 8.4の一様分布とする。

プレート境界地震とその他の地震による危険度を組み 合わせた結果を図一 5,6 に示す。図一5にはプレート境 界地震を除いた危険度, 線震源による危険度, それらの 和を別々に示した。東京では, 歴史地震の震源位置に最 も近いモデルであるCASE 1 を用いた場合に，確率モ デルによる結果が，累積頻度分布による結果に近づく。 断層面の半分もしくは全部で地震が一様に発生し得ると した場合， $y=5$ (再現期間 150 年）までは CASE 1 と 同じであるが，それより大きな $y$ に対しては基盤速度 がかなり大きくなる。大阪でもCASE 1 の結果が累積 頻度分布による結果とよく一致しているが, 東京に比べ 

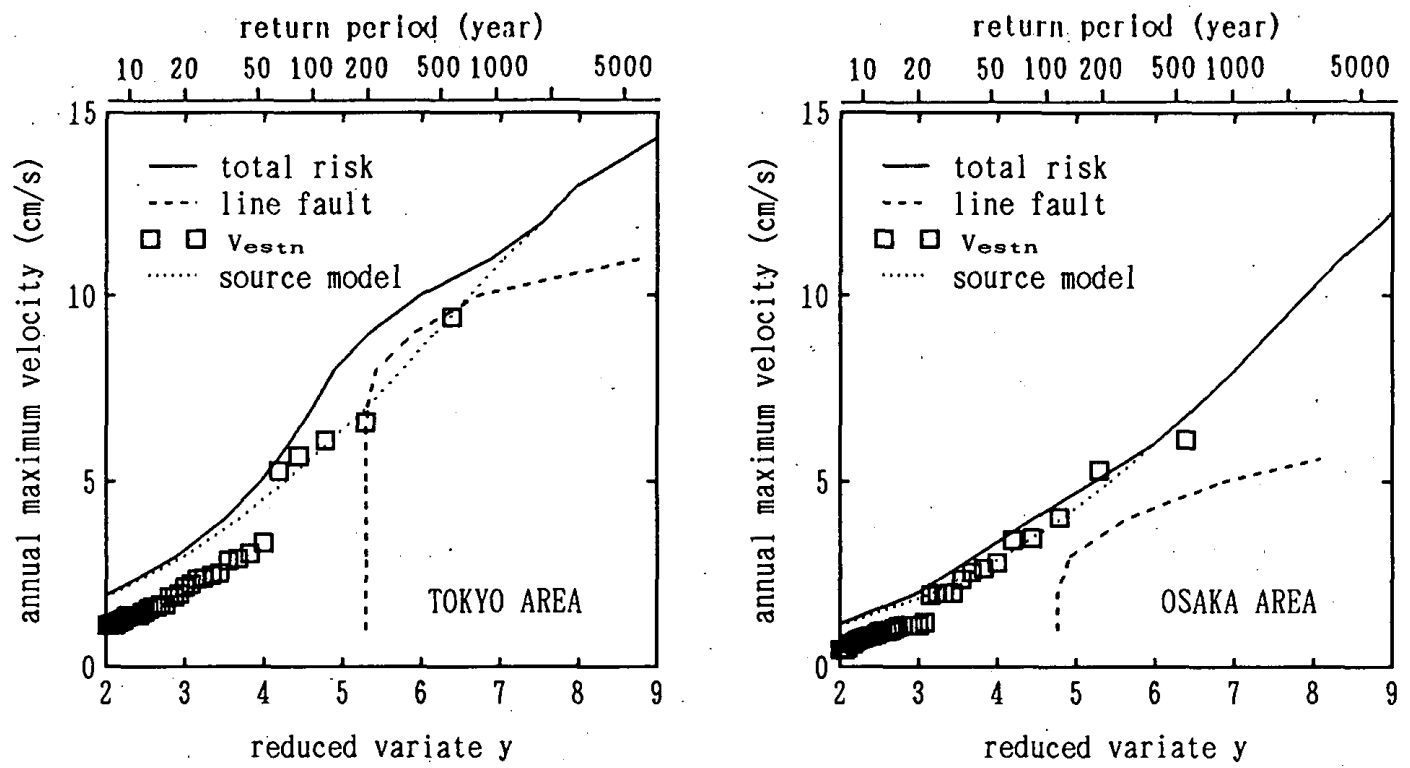

図一5 断層モデルを用いた地震危険度（CASE 1)
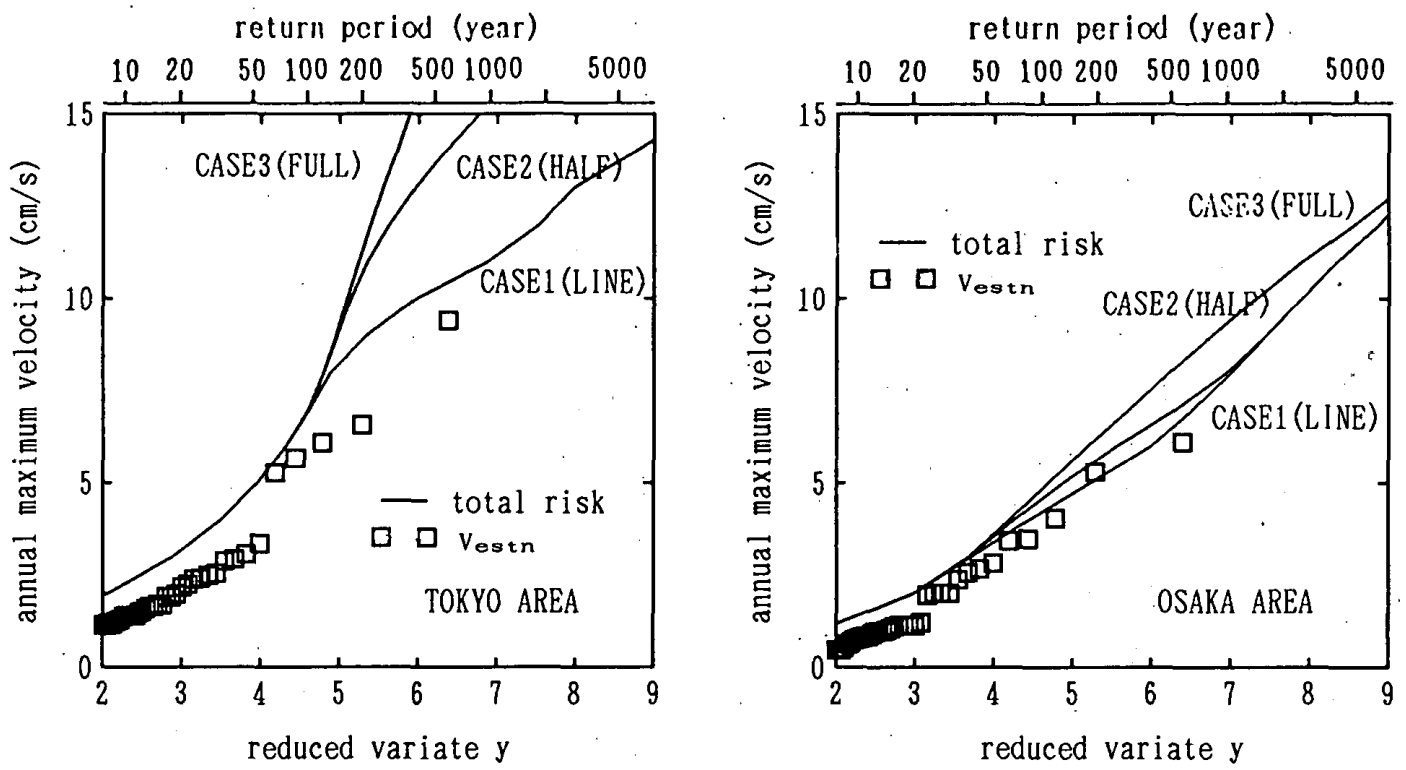

図一6＼cjkstart断層モデルを用いた地震危険度

てプレート境界地震の影響ばあまり大きくない。断層震 源域を大きくするにつれて基盤速度値は増すが，断層位 置が遠いため増加傾向は東京ほど顕著ではない。

\section{5. 地震発生の非定常性を考慮したモデル}

その地域の主要な地震発生サイクルを十分にカバーす るような長期間の地震危険度評価では地震発生をポアソ ン過程としたモデル化が妥当であるが，短期間の地震危 険度を評価する場合，地震発生の非定常性を考慮する必 要があると言われている ${ }^{18)}$ 。ここでは, プレート境界地 震の発生が再生過程に従うとした場合の地震危険度につ いて，単純なモデルを用いて検討する。

地震発生間隔 $T$ の確率分布 $F_{r}(t)$ にはワイブル分布 が用いられることが多く,ここでもワイブル分布と仮定

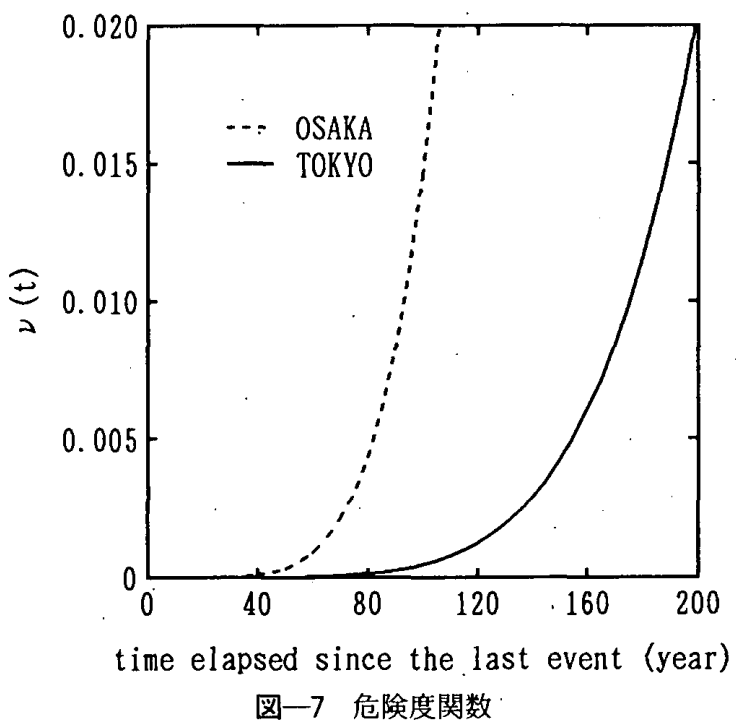



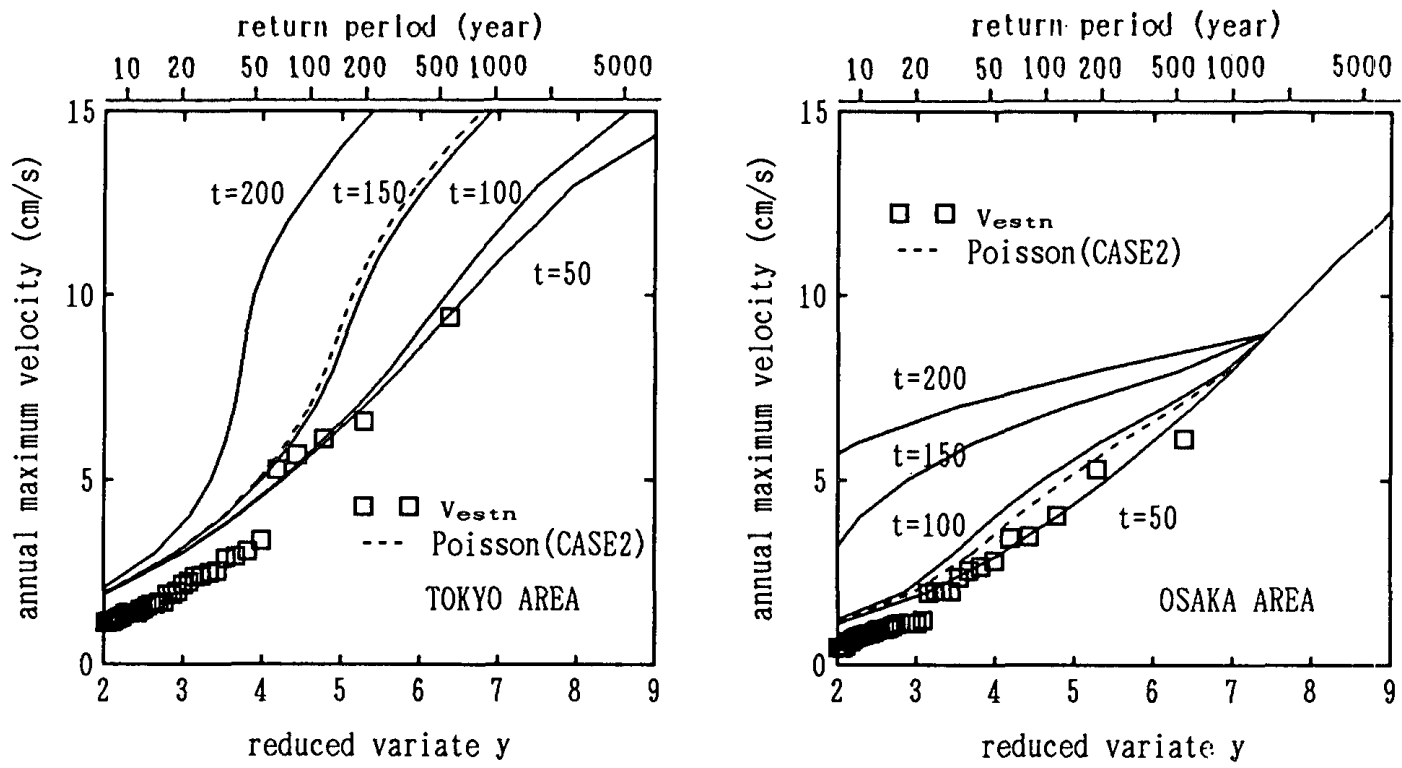

図一8＼cjkstart経過時間による地震危険度の変化

すると

$$
F_{T}(t)=1-\exp \left(-\alpha t^{\eta}\right)
$$

南海トラフでは, $\mathrm{Utsu}^{17)}$ が南海道で発生した 6 回の大 地震（1361 年～ 1946 年, $M \geqq 7.9 ）$ について求めたパ ラメータ $a=2.98 \times 10^{-14}, \gamma=6.44$ を用いる。平均発生 間隔は 117 年, 標準偏差は 21 年である。

相模トラフでは, 大地震の発生が 2 回しか記録されて おらず歴史地震資料だけから発生間隔の確率分布を決定 することはできない。Wesnousky ら ${ }^{16)}$ は地震発生間隔 の確率分布を正規分布と仮定し, 断層変位データから平 均発生間隔 200 年, 標準偏差 20 年とした。標準偏差を 20 年とした場合，地震発生時期はかなり限定される。 ここでは, 平均発生間隔 200 年のワイブル分布を用い, 変動係数は南海トラフと同じ 0.18 と仮定して標準偏差 は 36 年とする。これらの值に対応するワイブル分布の パラメータは $\alpha=7.0 \times 10^{-16}, \gamma=6.5$ となる。

危険度関数 $\nu(t)$ を,

$$
\nu(t)=\frac{1}{1-F_{\pi}(t)} \frac{d F_{\mathrm{T}}(t)}{d t}
$$

とすれば, 前回の地震発生から $t$ 年間地震が発生せず, 今後 $\Delta t$ 年間に地震動の大きさ $Y_{\Delta t}$ がある值 $y$ を超過す る確率は次式で与えられる19)。

$$
P_{t}\left(Y_{\Delta t}>y\right)=1-\exp \left\{-\int_{t}^{t+\Delta t} \nu(t) d t P(Y>y)\right\}
$$

ここで $\nu(t)$ が時間に関して一定 $(\gamma=1)$ であればポア ソン過程となり (4) 式と一致する。ワイブル分布の危 険度関数 $\nu(t)$ は次式で与えられる。

$$
\nu(t)=\alpha \gamma t^{\gamma-1}
$$

相模卜ラフおよび南海トラフの $\nu(t)$ の経時変化を図一7 に示す。 $\nu(t)$ がポアソン過程の年平均発生率と一致する
のは, 相模トラフで $t=150$ 年, 南海トラフで $t=90$ 年 程度である。

相模トラフ, 南海トラフでの前回の大地震発生（それ ぞれ 1923 年, 1946 年) から $t=50,100,150,200$ 年経 過した時点での基盤速度の年間超過確率を図一-8に示 す。プレート境界地震の震源域としては CASE 2 を用 いた。地震危険度は再生過程のプレート境界地震による ものと，ポアソン過程のその他の地震によるものの組み 合わせである。プレート境界地震もポアンン過程とした 前節の結果も同時に示す。ポアソン過程による結果は, 相模トラフで $t=150$ 年, 南海トラフで $t=90$ 年にほほ 対応している。 $t$ が増加するにつれてハザード曲線の立 ち上がり部分が左側に移動し，想定した震源域において プレート境界地震が確実に発生する場合のハザード曲線 に近づいていく。現時点（東京で $t=70$ 年, 大限で $t=$ 50 年程度) の地震危険度は, 東京, 大阪ともポアンン 過程よりも小さい。

\section{6. まとめ}

過去 300 年間の地震カタログと金井式を用いて，東京 および大阪地域の地震危険度を評価した。歴史地震によ る年最大基盤速度の累積頻度分布から得られる地震危険 度と, 確率モデルを用いて評価した地震危険度を比較し 以下の結論を得た。

(1) 緯度, 経度 $1^{\circ}$ 角の震源域を用いた確率モデルによ る結果は, 累積頻度分布による結果とおおむね一致する。 基盤速度の小さい部分では，歴史地震デー夕をそのまま 用いた累積頻度分布による危険度が，確率モデルによる 危険度よりも若干小さくなった。確率モデルによる基盤 速度の上限値は, サイト周辺の震源域の最大マグニ チュードに依存するため, 累積頻度分布による結果より 
も大きい。

(2) プレート境界地震を分離したモデルでは，震源域の 設定位置によってハザード曲線の形状が変化する。プ レート境界地震の震源域を広げていくと，東京地域では 再現期間の長い部分で, 累積頻度分布による值に比べて かなり大きな基盤速度值を与え，プレート境界地震の震 源域から遠い大阪地域ではあまり変化しない。 (3) プレート境界の地震発生に非定常性を考慮したモデ ルでは，時間の経過とともに危険度が増大し，プレート 境界地震が確奏に発生する場合のハザード曲線に近づい ていく。

震源域の設定，震源近傍での距離減衰式の扱い，震源 域の最大マグニチュードの設定等に関しては今後さらに 検討を加えていく必要があるが, プレート境界の地震動 を分離してモデル化することにより，より有効な地震危 険度解析手法を提案することができた。

\section{参考文献}

1）日本建築学会：地震荷重一その現状と将来の展望, 日本 建築学会, 昭和 62 年 11 月

2) Cornell, C. A. : Engineering Seismic Risk Analysis, Bull. Seism. Soc. Am., Vol.58, No.5, pp. 1583 1606, 1968. 10

3) Kawasumi H. : Measures of Earthquake Danger and Expectancy of Maximum Intensity Throughout Japan as Inferred from the Seismic Activity in Historical Times, Bull. Earthq. Res. Inst., Vol.29, pp. 469 482, 1951

4）戸松征夫, 安田 実, 片山恒雄 : 陸上活断層資料に基つ く地震危険度図の特徵, 土木学会第 17 回地震工学研究発 表会講演概要, pp. 21 24, 1983

5）壇，一男，神田 順：上下限值を有する極值分布を用い た地震危険度解析, 日本建築学会構造系論文報告集, 第 363 号, pp. 50 56, 昭和 61 年 5 月

6）宇佐美龍夫：新編日本被害地震総覧, 東京大学出版会, 1987

7）宇津徳治：日本付近の $M 6.0$ 以上の地震および被害地震 の表, 1885 年 1980 年, 地震研究所巣報, Vol. 57 , pp. 401 463, 1982
8）気象庁：地震月報，1926 1985

9) Kanai, K., Hirano, K. and Yoshizawa, S. : Observation of Strong Earthquake Motions in Matsushiro Area, Part 1, Bull. Earthq. Res. Inst. Vol.44, pp.1269 1296,1966

10）松村和雄, 牧野 稔：ポアソン確率モデルから求められ る最大地動の極值分布, 日本建築学会論文報告集, 第 273 号, pp. $55 \sim 62$, 昭和 53 年 11 月

11) McGuire, R. K. : FORTRAN Computer Program for Seismic Risk Analysis, U.S. Geological Survey OpenFile Report 76 67, 1976

12) Katayama, T. : Seismic Risk Analysis in terms of Acceleration Response Spectra, Proc. 2nd U.S. National Conference on Earthquake Engineering, pp. 117 126, 1979

13) Makino, M. and Matsumura, K. : A Correlation between The Recurrence Intervals of Active Faults and The Extreme Value Distributions of Earthquake Ground Motions, 第 5 回日本地震工学シンポジウム講演集, pp. 17 24, 1978

14) Matsu'ura M. et al. : Statical and Dynamical Study on Faulting Mechanism of the 1923 Kanto Earthquake, J. Phys. Earth, Vol.28, pp.119 143, 1980

15）相田 勇: 南海道沖の津波の数値実験, 地震研究所䩦報, Vol. 56, pp. 713 730, 1981

16) Wesnousky, S. G. et al. : Integration of Geological and Seismological Data for the Analysis of Seismic Hazard, A Case Study of Japan, Bull. Seism. Soc. Am., Vol. 74, No. 2, pp. 687 708. 1984. 4

17) Utsu, T. : Estimation of Parameters for Recurrence Models of Earthquakes, Bull. Earthq. Res. Inst., Vol. 59, pp. 53 66, 1984

18) Kameda, H. and Takagi, H. : Seismic Hazard Estimation Based on Non-Poisson Earthquake Occurrences, Momoirs of the Faculty of Engineering, Kyoto Univ., Vol. 43, Part 3, 1981.7

19) Savy, J. B. et al. : Nonstationary Risk Model with Geophysical Input, Journal of the Structural Division, ASCE, ST1, pp. 145 163, 1980. 1

(1992 年 5 月 8 日原稿受理, 1992 年 9 月 25 日採用決定) 